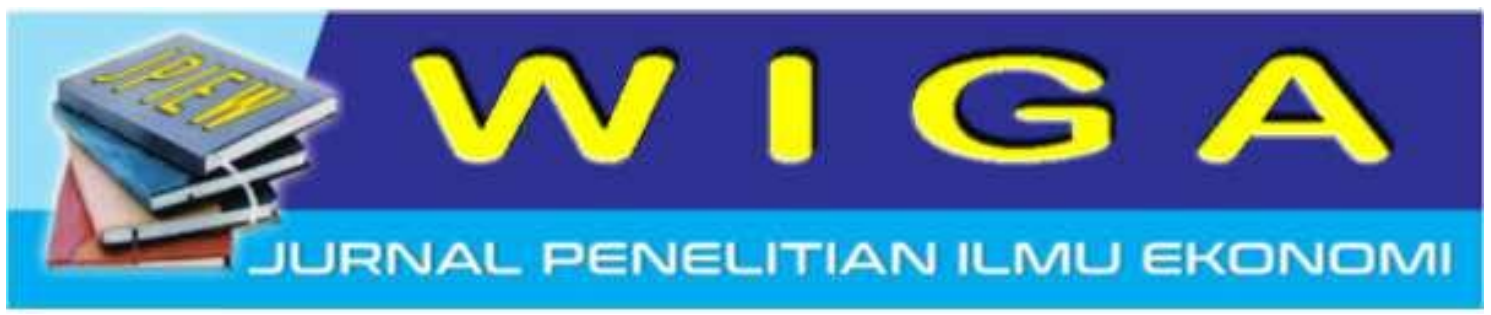

\title{
Analisis Pengaruh Rasio Early Warning System Terhadap Financial Solvency Pada Perusahaan Asuransi Jiwa Syariah Di Indonesia
}

\author{
Kris Ulfan ${ }^{1}$ \\ Mahasiswa Program Studi Magister Manajemen, Universitas Merdeka Malang, Indonesia \\ Chrisulfan hardynando@yahoo.com \\ Sutriswanto ${ }^{2}$ \\ Gaguk Apriyanto ${ }^{3}$ \\ Dosen Fakultas Ekonomi dan Bisnis, Universitas Merdeka Malang, Indonesia
}

\begin{abstract}
Abstrak
Penelitian ini bertujuan untuk menguji pengaruh rasio Early Warning System yang terdiri dari rasio perubahan surplus, rasio beban klaim, rasio biaya manajemen, rasio likuiditas dan rasio pertumbuhan premi terhadap financial solvency perusahaan asuransi jiwa syariah di Indonesia periode 2012 2016. Data yang digunakan adalah data sekunder yang diperoleh dari situs Asosiasi Asuransi Syariah Indonesia (AASI). Teknik pengambilan sampling yang digunakan dalam penelitian ini adalah purposive sampling. Sampel yang digunakan dalam penelitian ini sebanyak 10 perusahaan asuransi jiwa syariah. Pengujian hipotesis dengan menggunakan analisis regresi linier berganda. Hasil penelitian ini membuktikan bahwa financial solvency pada perusahaan asuransi jiwa syariah periode 2012 - 2016, dengan nilai rata - rata sebesar 507,68 \% dengan nilai financial solvency minimum sebesar $126,83 \%$ dan nilai maksimum sebesar $2447,50 \%$. Variabel yang berpengaruh terhadap financial solvency pada periode penelitian ini adalah rasio beban klaim dan rasio likuiditas yang menunjukkan pengaruh negatif dan signifikan. Rasio perubahan surplus, rasio biaya manajemen, rasio pertumbuhan premi terbukti tidak berpengaruh signifikan terhadap financial solvency. Rasio Early Warning System pada penelitian ini terbukti berpengaruh terhadap financial solvency pada level kemampuan prediksi sebesar $25,5 \%$ sebagai mana ditunjukkan pada nilai adjusted $R$ square. Variabel lain yang tidak terdapat dalam penelitian ini mempunyai pengaruh terhadap financial solvency sebesar $74,5 \%$.
\end{abstract}

Kata kunci : Asuransi Jiwa Syariah, Financial Solvency, Rasio Early Warning System

\begin{abstract}
This study aims to examine the influence of the Early Warning System ratio which consist of surplus change ratio, claim load ratio, cost management ratio, liquidity ratio and premium growth ratio to financial solvency of sharia life insurance company in Indonesia period 2012 - 2016. The data used are secondary data obtained from the website of Asosiasi Asuransi Syariah Indonesia ( $A A S I$ ). Sampling technique used in this research is purposive sampling. The sample used in this research is 10 sharia life insurance companies. Hypothesis testing by using multiple linear regression analysis. The results of this study prove that financial solvency at the sharia fairyde 2012 - 2016, with an average value of $507.68 \%$ with a minimum financial solvency of $126.83 \%$ and a maximum value of $2447.50 \%$. The variables that affect the financial solvency in this period of research are the ratio of claims expense and liquidity ratio which shows the negative and significant influence. Surplus change ratios, management expense ratios, the ratio of premium growth proved to be no significant effect on financial solvency. The ratio of Early Warning System in this study proved to have an effect on the financial solvency at the predictive ability level of $25.5 \%$ as shown in the adjusted $R$ square value. Other variables not found in this research have influence to financial solvency equal to $74,5 \%$.
\end{abstract}

Keywords: Syariah Life Insurance, Financial Solvency, Early Warning System ratio

WIGA : Jurnal Penelitian Ilmu Ekonomi, Volume 8 Nomor 1 | 12 


\section{PENDAHULUAN}

Kesadaran masyarakat tentang asuransi dalam kehidupannya, sudah mulai meningkat dibandingkan pada waktu 10 tahun yang lalu. Bahkan, dewasa ini pertumbuhan asuransi syariah sangat tinggi karena banyak masyarakat yang sadar akan pentingnya mempunyai asuransi. Asuransi syariah juga mempunyai banyak keunggulan dibandingkan dengan asuransi nonsyariah atau konvensional. Bagi masyarakat muslim diwajibkan untuk menghindari hal - hal yang bersifat riba sehingga mendorong pertumbuhan berbagai macam produk keuangan berbasis syariah termasuk asuransi syariah.

Asuransi syariah dalam menjalankan usahanya hanya menggunakan pedoman yang dikeluarkan Dewan Syariah Nasional Majelis Ulama Indonesia, yaitu fatwa Nomor 21/DSN$\mathrm{MUI} / \mathrm{X} / 2001$ tentang pedoman umum asuransi syariah. Dalam fatwa tersebut berisikan pedoman umum asuransi syariah, antara lain adalah usaha saling tolong - menolong diantara sejumlah pihak melalui investasi dalam bentuk aset atau tabarru', selain itu untuk menghadapi risiko tertentu melalui akad yang tidak mengandung gharar ( penipuan), maysir ( perjudian ), riba ( bunga ), zhulm ( penganiayaan ), risyiwah ( suap ) serta barang haram dan maksiat. Akad yang lain yang juga diatur dalam fatwa tersebut adalah tijarah ( komersial ), premi dan klaim ( Puspitasari, 2015 : 2 ). Berdasarkan ajaran agama islam fatwa tersebut didukung dengan adanya hadits Nabi SAW riwayat Imam Muslim yang digambarkan adanya sikap saling tolong menolong diantara umat islam bagaikan satu tubuh, jika ada satu anggota masyarakat yang sakit maka yang lain ikut merasakan ( Nafis, $2013: 31$ ).

Pemerintah pada Oktober 2016 mengadakan kuliah umum yang dilakukan oleh menteri keuangan RI Sri Mulyani Indrawati dalam Indonesia Syari'a Economic Festival ( ISEF ) di Surabaya. Dalam kuliah tersebut pemerintah akan mendorong percepatan ekonomi syariah di Indonesia dengan membentuk Komite Nasional Keuangan Syariah ( KNKS ). Tujuan dibentuknya komite syariah tersebut

Salah satunya adalah untuk mempercepat perkembangan seluruh aspek keuangan syariah yang ada di Indonesia termasuk asuransi syariah.

Ernest \& Young ( 2010 ) dalan Jurnal Asuransi dan Manajemen Risiko mengemukakan bahwa selama tahun 2007 sampai dengan 2008 konstribusi premi asuransi syariah mencapai $28 \%$ dari seluruh kegiatan perekonomian di dunia. Agustina (
2011 ) menyatakan bahwa pada negara negara Islam asuransi syariah mampu menghasilkan premi hingga USD 1,7 miliar. Informasi lain yang dipublikasikan Ernest \& Young ( 2010 ) adalah Arab Saudi dan Malaysia merupakan dua negara yang memberikan konstribusi premi asuransi syariah terbesar di dunia. Arab Saudi berkonstribusi hingga lebih dari USD 2,9 miliar, sementara Malaysia USD 900 juta. Susilowati ( 2011 ) juga menambahkan bahwa Uni Emirat Arab dan Indonesia merupakan pasar dengan pertumbuhan asuransi syariah tercepat.

Berdasarkan data Asosiasi Asuransi Syariah Indonesia ( AASI ) pangsa pasar asuransi jiwa syariah dan reasuransi jiwa syariah pada kuartal III tahun 2012 hanya $3,96 \%$ ( AASI, 2013 ). Data tersebut menunjukkan bahwa kesadaran masyarakat Indonesia terhadap asuransi jiwa syariah masih rendah meskipun didukung dengan jumlah penduduk mayoritas muslim, sehingga perlu dilakukan edukasi terhadap masyarakat untuk meningkatkan pangsa pasar asuransi jiwa syariah di Indonesia. Penyebab rendahnya pangsa pasar perlu diselidiki apakah masyarakat mungkin masih tertarik pada keuntungan yang ditawarkan asuransi jiwa konvensional, masyarakat masih belum paham mengenai konsep asuransi jiwa syariah atau adanya masalah pada instrumen keuangan perusahaan asuransi jiwa syariah sehingga kepercayaan masyarakat rendah.

Kementerian Keuangan Indonesia pada tahun 2013 juga merilis bahwa dalam kurun waktu lima tahun terakhir ( 2008 - 2012 ) pasar asuransi jiwa syariah tumbuh sebesar $53 \%$ atau mencapai $\mathrm{Rp} 7.3$ triliun, pertumbuhan ini ternyata masih jauh lebih tinggi dibandingkan pertumbuhan premi asuransi jiwa konvensional yang hanya tumbuh sebesar $15,93 \%$. Pendapatan premi asuransi jiwa syariah hingga akhir tahun 2011 sebesar Rp 4,99 triliun atau 34,9\%.

Menurut Puspitasari ( $2015: 132$ )

kinerja keuangan menunjukkan prestasi atau hasil kinerja perusahaan asuransi pada periode tertentu. Kinerja tersebut dianalisis menggunakan laporan keuangan yang memiliki indikator khusus, dikarenakan adanya perbedaan sifat dan karakteristik perusahaan asuransi dengan perusahaan lainnya. Pengukuran indikator tersebut menggunakan rasio - rasio keuangan untuk mengetahui seberapa baik atau buruk kinerja suatu perusahaan khususnya perusahaan asuransi jiwa syariah.

Salah satu jenis rasio yang digunakan untuk menilai kinerja perusahaan asuransi jiwa syariah adalah rasio sistem peringatan dini atau lebih dikenal dengan Early Warning 
System ( EWS ). Rasio EWS merupakan tolok ukur perhitungan dalam perkiraan seperti aktiva, kewajiban, modal dan profit perusahaan ( Detiana, 2012 ). Rasio EWS dibuat oleh The National Association Of Insurance Commissioner (NAIC) dan biasanya digunakan untuk mengukur untuk mengukur kinerja perusahaan asuransi yang ada di Amerika Serikat. Tujuan dari EWS adalah mempermudah lembaga pengawasan perasuransian yang ada di Amerika Serikat untuk melakukan identifikasi hal - hal yang berkaitan dengan pembinaan dan pengawasan perusahaan asuransi ( Prasetyo, 2015). Rasio EWS dipilih karena sudah mencakup perhitungan rasio likuiditas, solvabilitas dan profitabilitas. Namun karena perusahaan asuransi memiliki karakter yang berbeda dengan perusahaan lain. Maka rasionya perlu disesuaikan seperti adanyan rasio yang mengukur premi asuransi, rasio beban klaim, dan lain sebagainya. Laporan kinerja keuangan pada perusahaan asuransi baik konvensional maupun dengan prinsip syariah berbeda dengan perusahaan yang bergerak dibidang keuangan lain, akan tetapi laporan kinerja keuangan perusahaan asuransi memiliki standart dan aturan tersendiri.

Rasio EWS yang digunakan dalam penelitian ini, dipilih karena memiliki alasan yang berbeda - beda satu dengan yang lain. Rasio perubahan surplus dipilih dikarenakan menggambarkan peningkatan / penurunan kondisi keuangan perusahaan asuransi, rasio beban klaim dipilih untuk menilai proses penutupan risiko yang dilakukan oleh perusahaan, rasio biaya manajemen untuk memberikan gambaran kemampuan perusahaan membiayai seluruh aktifitas manajemen yang dilakukan, rasio likuiditas dipilih untuk memberikan gambaran secara menyeluruh tentang kondisi keuangan perusahaan, rasio pertumbuhan premi untuk menilai kestabilan operasi perusahaan. Selain beberapa alasan di atas pemilihan rasio tersebut juga didasarkan pada hasil penelitian terdahulu sebagai referensi yang digabungkan untuk menghasilkan suatu hasil penelitian terbaru.

Penelitian sebelumnya yang dilakukan oleh Hasbi dan Suryawardani (2013) yang meneliti sistem peringatan dini ( rasio agregat surplus, rasio biaya manajemen, rasio premi utang terhadap surplus ) terhadap tingkat solvabilitas ( $\mathrm{RBC}$ ) perusahaan asuransi syariah. Hasil dari penelitian ini secara parsial maupun simultan berpengaruh signifikan terhadap tingkat solvabilitas perusahaan asuransi syariah. Hasil penelitian Oktaviani ( 2015 ) rasio Early Warning System yang diproyeksikan dengan rasio solvency margin, agent's balance to surplus ratio, rasio perubahan surplus, rasio pengembalian investasi, rasio likuiditas dan rasio cadangan teknis terhadap pertumbuhan pendapatan premi konstribusi. Hasil dari penelitian ini rasio early warning system berpengaruh secara simultan terhadap rasio pertumbuhan premi konstribusi. Secara parsial rasio solvency margin, rasio rasio perubahan surplus, rasio pengembalian investasi berpengaruh negatif terhadap pertumbuhan pendapatan premi konstribusi, sedangkan agent's balance to surplus ratio dan rasio cadangan teknis berpengaruh positif terhadap pertumbuhan pendapatan premi konstribusi. Dari penelitian Oktaviani dapat disimpulkan bahwa rasio Early Warning System dapat diterapkan dalam rangka meningkatkan pertumbuhan pendapatan premi konstribusi perusahaan asuransi jiwa syariah.

Penelitian terdahulu di atas menggunakan rasio EWS untuk mengukur kinerja perusahaan asuransi. Variabel dependen yang diukur merupakan nilai perusahaan yang menjadi indikator keberhasilan kinerja keuangan perusahaan antara lain, tingkat solvabilitas, pertumbuhan pendapatan premi konstribusi. Variabel pengukuran dalam penelitian sebelumnya berbeda satu dengan yang lain. Sedangkan pada penelitian ini yang membedakan dengan penelitian sebelumnya adalah menggunakan financial solvency untuk mengukur sejauh mana perusahaan asuransi jiwa syariah yang ada di Indonesia dapat membiayai seluruh kegiatan operasional dan ditambah dengan variabel independen, antara lain perubahan surplus, beban klaim, biaya manajemen, likuiditas dan pertumbuhan premi. Maksud dari pemilihan serta penggabungan variabel variabel dalam penelitian untuk mengetahui tingkat signifikan dan keakuratan pengaruh dari variabel dependen terhadap variabel independen secara parsial dan secara simultan yang belum pernah dilakukan penelitian sebelumnya, untuk mengetahui tingkat keberhasilan dalam operasional keuangan pada perusahaan asuransi jiwa syariah.

\section{KAJIAN PUSTAKA \\ Asuransi Syariah}

Definisi asuransi menurut Undang Undang Republik Indonesia Nomor 2 tahun 1992 tentang usaha perasuransian Bab I, Pasal 1 : Asuransi atau pertanggungan adalah perjanjian antara dua belah pihak penanggung mengingatkan diri kepada tertanggung dengan menerima premi asuransi, untuk memberikan penggantian kepada tertanggung karena kerugian, kerusakan atau kehilangan keuntungan yang diharapkan atau tanggung jawab hukum kepada pihak ketiga yang 
mungkin akan diderita tertanggung, yang timbul dari suatu peristiwa yang tidak pasti atau untuk memberikan pembayaran yang didasarkan atas meninggal atau hidupnya seseorang yang dipertanggungkan.

Menurut Fatwa Dewan Syariah Nasional Majelis Ulama Indonesia (DSN-MUI) Fatwa DSN No.21/DSN-MUI/X/2001 Asuransi syariah adalah usaha saling melindungi dan tolong menolong diantara sejumlah orang atau pihak melalui investasi dalam bentuk aset atau tabarru' yang memberikan pola pengembalian untuk menghadapi risiko tertentu melalui akad atau perikatan yang sesuai dengan prinsip syariah.

Di dalam bahasa Arab asuransi dikenal dengan istilah at takaful atau at Tadhamun yang berarti saling menanggung. Asuransi ini disebut juga dengan istilah at Ta'min berasal dari kata amina yang berarti aman, tentram dan tenang. Dinamakan at Ta'min karena orang yang melakukan transaksi ini (khususnya peserta) telah merasa aman dan tidak terlalu takut terhadap bahaya yang menimpanya dengan adanya transaksi ini ( Puspitasari, 2015:2 ). Dari beberapa pengertian diatas dapat disimpulkan bahwa asuransi syariah adalah suatu pengaturan pengelolaan risiko yang memenuhi ketentuan Syariah, tolong menolong secara mutual yang melibatkan peserta dan operator perusahaan asuransi syariah.

\section{Financial Solvency}

Financial Solvency merupakan Alat ukur yang digunakan untuk mengetahui seberapa sehat atau kemampuan kondisi keuangan suatu perusahaan asuransi jiwa syariah dapat memenuhi semua kebutuhan operasionalnya. Financial Solvency menurut pendapat Smirnov \& Zdorovenin (2012) merupakan rasio pengukuran jumlah modal minimum yang harus dimiliki oleh sebuah perusahaan asuransi untuk mendorong kegiatan operasional.

Menurut Fahmi ( $2014: 51$ ) financial solvency merupakan kondisi bagaimana perusahaan mampu mengelola utangnya dalam rangka memperoleh keuntungan dan juga mampu kembali melunasi hutangnya. Rasio ini mengukur kemampuan perusahaan memenuhi kewajiban - kewajiban dalam jangka panjang. Perusahaan dikatakan tidak solvabel adalah perusahaan yang total utangnya lebih besar dari total aset yang dimilikinya. Namun harus dipahami bahwa bukan berarti perusahaan yang insolvabel namun likuid bisa menjalankan aktivitasnya. Karena dengan kemampuan likuiditas yang dimilikinya sangat memungkinkan perusahaan tersebut untuk bisa mengembalikan utangnya dengan cepat dan tepat. Pendapat lain menyatakan bahwa financial solvency merupakan selisih kekayaan perusahaan asuransi yang dikurangi dengan seluruh kewajiban yang harus dibayarkan. Pendapat tersebut didukung oleh penelitian yang dilakukan Hasbi \& Suryawardani ( 2013 ), dalam penelitian tersebut financial solvency diukur dengan tingkat solvabilitas mengacu pada pengukuran yang ada pada risk based capital (RBC).

Perusahaan asuransi harus memiliki total kekayaan yang lebih besar dari pada total kewajiban yang harus dibayarkan pada periode tertentu. Untuk itu agar perusahaan dapat mengetahui kondisi keuangan serta kewajiban yang harus dibayarkan, maka perlu dilakukan analisis terhadap rasio - rasio keuangan pada perusahaan asuransi. Rasio yang digunakan sebagai peringatan kinerja perusahaan asuransi adalah rasio early warning sistem. Dalam rasio ews perusahaan asuransi akan dianalisis dengan serangkaian rasio - rasio yang ada didalamnya, antara lain rasio perubahan surplus, rasio beban klaim, rasio biaya manajemen, rasio likuiditas Puspitasari, 2011).

\section{Early Warning System ( EWS )}

Mengingat industri asuransi memiliki karakter yang berbeda dengan industri industri lain, sehingga jenis - jenis perkiraan dalam laporan keuangannya juga berbeda. Perbedaan mendasar antara industri asuransi dengan industri lain pada umumnya terletak pada fungsi underwriting (pengelolaan risiko) dan fungsi penanganan klaim. Karena adanya perbedaan karakteristik tersebut beberapa rasio keuangan tentu perlu disesuaikan. Untuk industri asuransi rasio - rasio yang digunakan dibuat dalam suatu sistem penilaian yang disebut early warning system, yaitu tolok ukur yang digunakan oleh The National Association Of Insurance Commisioners ( NAIC ) atau lembaga pengawas badan usaha asuransi Amerika Serikat dalam mengukur kinerja keuangan dan menilai tingkat kesehatan perusahaan asuransi ( Prasetyo, 2015 ).

Early Warning System ( EWS ) merupakan penyediaan informasi yang tepat waktu dan efisien melalui lembaga - lembaga teridentifikasi yang memungkinkan individu untuk mengambil tindakan untuk menghindari atau mengurangi risiko dan mempersiapkan respon yang efektif. EWS pada dasarnya terdiri dari empat unsur utama, yaitu Risk Knowledge : penilaian menyediakan informasi penting untuk menetapkan prioritas dalam mitigasi, pencegahan strategi dan merancang sistem peringatan dini, Monitoring dan Predicting : sistem dengan pemantauan dan kemampuan memprediksi memberikan perkiraan potensi risiko tepat waktu yang 
dihadapi masyarakat, ekonomi dan lingkungan, Disseminating Information : sistem informasi yang diperlukan untuk mengirim pesan peringatan kepada lokasi yang terkena dampak untuk megingatkan lembaga pemerintahan lokal dan regional, Response : koordinasi, tata kelola yang baik dan rencana tindakan yang tepat adalah poin penting dalam peringatan dini yang efektif.

EWS dalam bidang keuangan, misalnya terdiri dari lembaga - lembaga keuangan yang terdiri dari bank, ekonomi, financial distress, asuransi dan saham. Satria ( 2012 : 158 ) menyatakan bahwa EWS merupakan rasio - rasio yang digunakan untuk menganalisis dan mengatur tingkat kesehatan dan kinerja perusahaan asuransi jiwa dengan mendeteksi lebih awal dari kekurangcairan keuangan di masa yang akan datang untuk menentukan prioritas langkah - langkah perbaikan bagi perusahaan, yang dibuat khusus untuk perusahaan asuransi. Dibanyak negara perhitungan EWS digunakan untuk membantu pengawasan asuransi dengan mengukur kinerja keuangan dan menilai tingkat kesehatan perusahaan asuransi, mengidentifikasi perusahaan yang membutuhkan pemantauan lebih ketat dan segera serta menentukan tingkat (grading) perusahaan asuransi.

Dari beberapa penelitian di atas dapat disimpulkan bahwa rasio EWS adalah salah satu rasio keuangan yang menjadi tolok ukur dalam mengukur kinerja keuangan dan menilai tingkat kesehatan perusahaan asuransi sehingga dapat memberikan persiapan dalam menghadapi ancaman yang mungkin mempengaruhi kondisi keuangan dan kinerja perusahaan asuransi khususnya.

Berdasarkan perumusan masalah, landasan teoritis dan hasil penelitian sebelumnya, tujuan penelitian ini adalah untuk mengetahui apakah rasio EWS (rasio perubahan surplus, rasio beban klaim, rasio biaya manajemen, rasio likuiditas dan rasio pertumbuhan premi) yang digunakan untuk mengukur kinerja keuangan memiliki pengaruh secara parsial dan simultan terhadap Financial Solvency perusahaan asuransi jiwa syariah. Model kerangka konseptual dalam penelitian ini digambarkan sebagai berikut :

\begin{tabular}{|c|}
\hline \multicolumn{1}{|c|}{ Early Warning System } \\
\hline $\begin{array}{c}\text { Rasio Perubahan Surplus } \\
\text { ( X1 ) }\end{array}$ \\
\hline $\begin{array}{c}\text { Rasio Beban Klaim } \\
\text { ( X2 ) }\end{array}$ \\
\hline $\begin{array}{c}\text { Rasio Biaya Manajemen } \\
\text { ( X3 ) }\end{array}$ \\
\hline \hline $\begin{array}{c}\text { Rasio Likuiditas } \\
\text { ( X4 ) }\end{array}$ \\
\hline
\end{tabular}

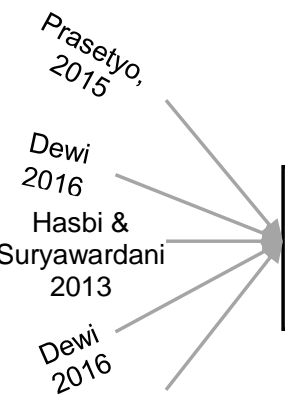

Financial Solvency

( $\mathrm{Y}$ ) Rasio Pertumbuhan
Premi ( X5)

\author{
Gambar 1 \\ Model Kerangka Konsep Variabel \\ Penelitian \\ Hasbi \& Suryawardani, 2013
}

\section{Hipotesis Penelitian}

Berdasarkan landasan teori dan kerangka konseptual yang telah dipaparkan diatas, maka dapat disusun hipotesis dalam penelitian ini sebagai berikut :

H.1 Diduga Rasio EWS yang terdiri dari rasio perubahan surplus, rasio beban klaim, rasio biaya manajemen, rasio likuiditas dan rasio pertumbuhan premi secara bersama - sama berpengaruh signifikan terhadap Financial Solvency pada perusahaan asuransi jiwa syariah di Indonesia.

H.2 Diduga Rasio perubahan surplus berpengaruh signifikan terhadap Financial Solvency pada perusahaan asuransi jiwa syariah di Indonesia.

H.3 Diduga Rasio beban klaim berpengaruh signifikan terhadap Financial Solvency pada perusahaan asuransi jiwa syariah di Indonesia.

H.4 Diduga Rasio biaya manajemen berpengaruh signifikan terhadap Financial Solvency pada perusahaan asuransi jiwa syariah di Indonesia.

H.5 Diduga Rasio likuiditas berpengaruh signifikan terhadap Financial Solvency pada perusahaan asuransi jiwa syariah di Indonesia.

H.6 Diduga Rasio pertumbuhan premi berpengaruh signifikan terhadap Financial Solvency pada perusahaan asuransi jiwa syariah di Indonesia.

H.7 Diduga Rasio beban klaim berpengaruh dominan terhadap Financial Solvency pada perusahaan asuransi jiwa syariah di Indonesia.

\section{METODE PENELITIAN}

Metode yang digunakan dalam penelitian ini adalah kausalitas ( causal research ). Metode kausalitas adalah desain penelitian yang disusun untuk meneliti kemungkinan adanya hubungan sebab akibat antar variabel (Sanusi, 2014 : 14). Dalam desain ini pada umumnya hubungan sebab - akibat tersebut sudah dapat diprediksi oleh peneliti, sehingga peneliti dapat menyatakan klasifikasi variabel penyebab, variabel antara dan variabel terikat (tergantung). Pendekatan yang digunakan dalam penelitian ini adalah pendekatan kuantitatif, prosesnya diawali dengan penyusunan model teoritis dan analisis 
sebagai dasar pengajuan jawaban sementara ( hipotesis ), kemudian dilanjutkan dengan operasional konsep, sampai penyimpulan sebagai suatu temuan penelitian.

Populasi dalam penelitian ini adalah seluruh perusahaan asuransi jiwa yang memiliki unit syariah dan tergabung dalam AASI. Jumlah populasi dalam penelitian adalah sebanyak 19 perusahaan asuransi jiwa syariah, namun tidak semua anggota populasi ini menjadi objek penelitian, teknik pengambilan sampel dengan metode purpose sampling. Purpose sampling adalah pengambilan sampel berdasarkan keperluan penelitian, artinya setiap unit / individu yang diambil dari populasi dipilih dengan sengaja berdasarkan pertimbangan tertentu ( Sulistyastuti \& Purwanto, 2011 : 66 ). Perusahaan asuransi jiwa yang memenuhi persyaratan untuk dijadikan sampel dalam penelitian ini sebanyak 10 perusahaan, sebagai berikut :

1. PT AIA Financial

2. PT Asuransi Allianz Life Indonesia

3. PT Asuransi Jiwa Beringin Jiwa Sejahtera

4. PT Asuransi Jiwa Manulife Indonesia

5. PT Asuransi Jiwa Sinarmas

6. PT AXA Financial Indonesia

7. PT Great Eastern Life Indonesia

8. PT Panin Daichi Life

9. PT Prudential Life assurance

10. PT Sun Life Financial Indonesia

Penelitian ini mengkaji tentang early warning system yang dicerminkan oleh rasio perubahan surplus, rasio beban klaim, rasio biaya manajemen, rasio likuiditas dan rasio pertumbuhan premi terhadap Financial Solvency pada perusahaan asuransi jiwa syariah di Indonesia periode 2012 - 2016. Masing - masing variabel dalam penelitian diuraikan pada tabel berikut :

Tabel 1 Operasional Variabel

\begin{tabular}{|c|c|c|c|c|}
\hline $\begin{array}{c}\text { Varia } \\
\text { bel }\end{array}$ & $\begin{array}{c}\text { Sub } \\
\text { Variabel } \\
\text { dan } \\
\text { Konsep }\end{array}$ & Indikator & $\begin{array}{l}\text { Uku } \\
\text { ran }\end{array}$ & $\begin{array}{c}\text { Ska } \\
\text { la }\end{array}$ \\
\hline $\begin{array}{l}\text { Early } \\
\text { Warn } \\
\text { ing } \\
\text { Syst } \\
\text { em } \\
\text { (X) }\end{array}$ & $\begin{array}{l}\text { Rasio } \\
\text { Perubahan } \\
\text { Surplus ( } \\
\text { X1 ! } \\
\text { Rasio ini } \\
\text { memberika } \\
\text { n indikasi } \\
\text { atas } \\
\text { perkemban } \\
\text { gan atau } \\
\text { penurunan } \\
\text { kondisi } \\
\text { keuangan } \\
\text { perusahan } \\
\text { dalam } \\
\text { tahun }\end{array}$ & $\begin{array}{c}\text { Perubahan Surplus } \\
= \\
\frac{\text { Perubahan (naik/turun) }}{\text { Modal SendiriTah }}\end{array}$ & $\%$ & $\begin{array}{c}\text { Ras } \\
\text { io }\end{array}$ \\
\hline
\end{tabular}

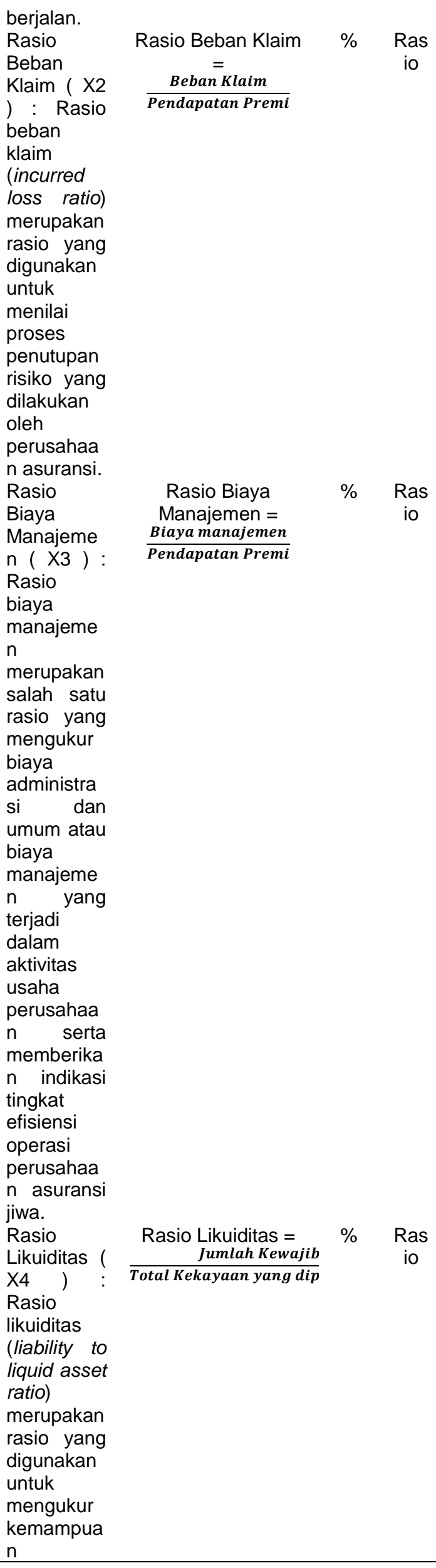




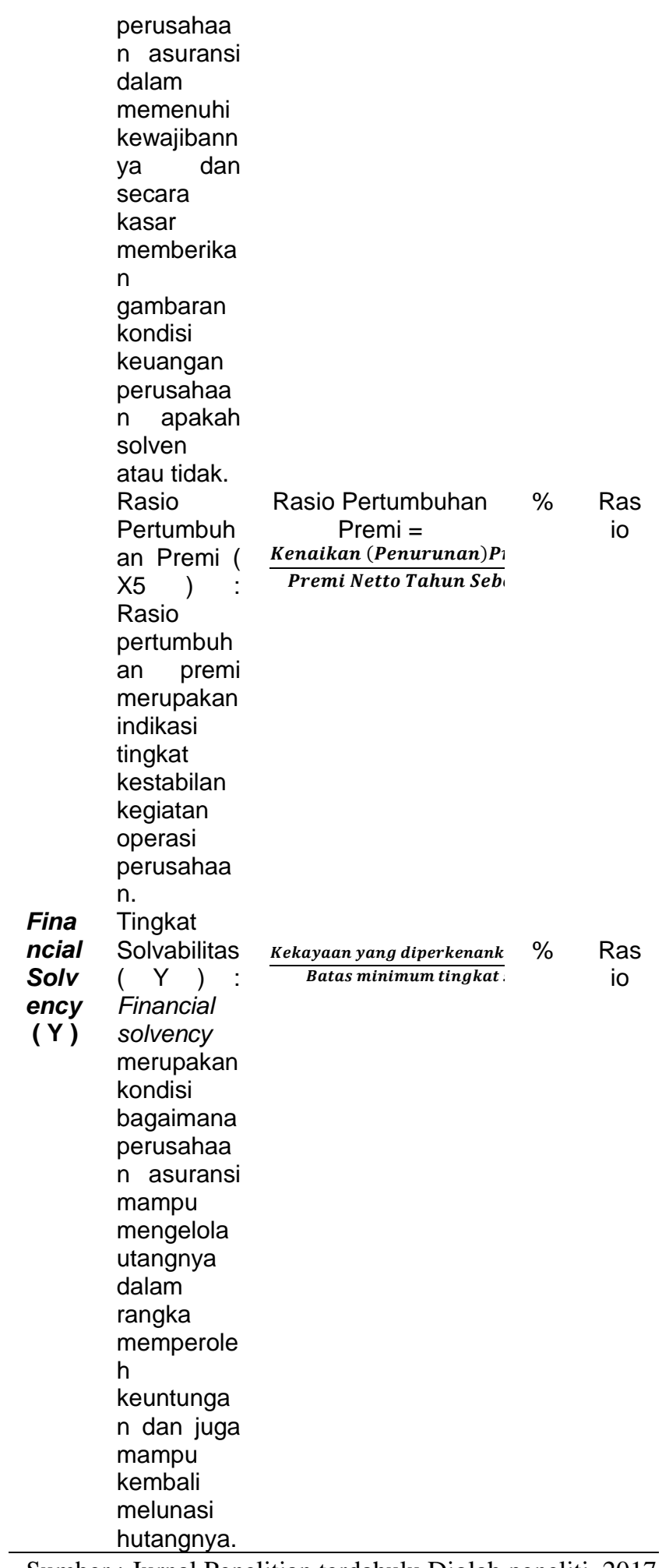

Sumber : Jurnal Penelitian terdahulu Diolah peneliti, 2017

Penelitian ini menggunakan data sekunder yang bersumber dari laporan keuangan tahunan perusahaan asuransi jiwa syariah yang menjadi anggota AASI selama periode 5 tahun ( 2012 - 2016 ). Data sekunder tersebut diambil pada situs web AASI, buku, jurnal yang memiliki hubungan dengan penelitian, berita on line mengenai asuransi syariah dan undang - undang tentang asuransi syariah di Indonesia.
Penelitian ini menggunakan analisis regresi linier berganda yang digunakan untuk menguji atau melakukan estimasi dari suatu permasalahan yang terdiri lebih dari satu variabel independen (Amirullah, 2013). Namun sebelumnya dilakukan uji asumsi klasik terlebih dahulu meliputi, uji normalitas, uji heteroskedastisitas, uji multikolinieritas, uji autokorelasi. Formulasi untuk analisis regresi linier berganda sebagai berikut :

$$
\begin{aligned}
& \text { Financial Solvency }(Y)=\alpha+\beta_{1} X_{1}+ \\
& \beta_{2} X_{2}+\beta_{3} X_{3}+\beta_{4} X_{4}+\beta_{5} X_{5}+\varepsilon
\end{aligned}
$$

Dimana :

$$
\alpha=\text { Konstanta / Intercept }
$$

$\beta_{1}-\beta_{5}=$ Koefisien regresi masing - masing variabel

$\mathrm{X}_{1}=$ Rasio Perubahan Surplus

$\mathrm{X}_{2}=$ Rasio Beban Klaim

$X_{3}=$ Rasio Biaya Manajemen

$\mathrm{X}_{4}=$ Rasio Likuiditas

$\mathrm{X}_{5}=$ Rasio Pertumbuhan Premi

$\varepsilon=$ Error term (variabel pengganggu) atau residual

Setelah itu langkah selanjutnya dilakukan ( uji F ) untuk mengetahui pengaruh variabel independen terhadap variabel dependen secara simultan dengan melihat besarnya nilai Adjusted $R$ Square yang menunjukkan seberapa besar pengaruh model menerangkan varibel dependen ( Kuncoro, 2011 ). Uji selanjutnya yang dilakukan adalah ( Uji t ), dilakukan untuk mengetahui pengaruh tiap variabel independen terhadap variabel dependen secara parsial.

\section{HASIL DAN PEMBAHASAN \\ Hasil Analisis Deskriptif}

Variabel dependen yang digunakan dalam penelitian ini adalah financial solvency. Hasil perhitungan analisis statistik deskriptif variabel dependen disajikan dalam tabel berikut :

Tabel 2 Hasil Analisis Statistik Deskriptif

\begin{tabular}{ll}
\hline Financial Solvency Ratio & \\
\hline Minimum & 126,83 \\
Maksimum & 2447,50 \\
Mean & 507,6784 \\
Std. Deviation & 479,36820 \\
\hline Sumber : Hasil analisis SPSS diolah, 2017 &
\end{tabular}

Pada tabel 2 menunjukkan bahwa nilai minimum financial solvency sebesar 126,83 yang terdapat pada perhitungan PT Sun Life Financial Indonesia tahun 2015, sedangkan nilai maksimum sebesar 2447,50 yang terdapat pada perhitungan PT AIA Financial tahun 2016. Nilai mean 507,6784 dengan Std. 
Deviation 479,36820 yang menunjukkan seberapa jauh nilai financial solvency ratio menyimpang dari nilai rata - ratanya.

Tabel 3 Hasil Analisis Statistik Deskriptif Variabel Independen

\begin{tabular}{|c|c|c|c|c|c|c|}
\hline $\begin{array}{c}\text { Variab } \\
\text { el }\end{array}$ & $\begin{array}{c}\mathrm{Mi} \\
\mathrm{n}\end{array}$ & $\begin{array}{c}\text { Peru } \\
\text { saha } \\
\text { an }\end{array}$ & $\begin{array}{c}\mathrm{Ma} \\
\mathrm{x}\end{array}$ & $\begin{array}{l}\text { Peru } \\
\text { saha } \\
\text { an }\end{array}$ & Mean & $\begin{array}{l}\text { Std. } \\
\text { Devi } \\
\text { ation }\end{array}$ \\
\hline $\begin{array}{l}\text { Perub } \\
\text { ahan } \\
\text { Surplu } \\
\text { s }\end{array}$ & $\begin{array}{c}- \\
23 \\
9 \\
0\end{array}$ & $\begin{array}{l}\text { Asur } \\
\text { ansi } \\
\text { Great } \\
\text { Easte } \\
\text { rn } \\
\text { Life } \\
\text { Indon } \\
\text { esia ( } \\
2015\end{array}$ & $\begin{array}{l}256 \\
, 72\end{array}$ & $\begin{array}{l}\text { Asuran } \\
\text { si AIA ( } \\
2012 \text { ) }\end{array}$ & $\begin{array}{l}37,3 \\
045\end{array}$ & $\begin{array}{l}44,8 \\
5453\end{array}$ \\
\hline $\begin{array}{l}\text { Beban } \\
\text { Klaim }\end{array}$ & $\begin{array}{l}1, \\
09\end{array}$ & $\begin{array}{l}\text { Asur } \\
\text { ansi } \\
\text { AIA ( } \\
2012 \\
\text { ) }\end{array}$ & $\begin{array}{l}76 \\
48\end{array}$ & $\begin{array}{l}\text { Asuran } \\
\text { si } \\
\text { Great } \\
\text { Easter } \\
\text { n Life } \\
\text { Indone } \\
\text { sia ( } \\
2012 \text { ) }\end{array}$ & $\begin{array}{l}22,2 \\
257\end{array}$ & $\begin{array}{r}18,1 \\
2411\end{array}$ \\
\hline $\begin{array}{l}\text { Biaya } \\
\text { Manaj } \\
\text { emen }\end{array}$ & $\begin{array}{c}10 \\
, 9 \\
1\end{array}$ & $\begin{array}{l}\text { Asur } \\
\text { ansi } \\
\text { Jiwa } \\
\text { Sinar } \\
\text { mas ( } \\
2012 \\
\text { ) }\end{array}$ & $\begin{array}{c}154 \\
3,8 \\
8\end{array}$ & $\begin{array}{l}\text { Asuran } \\
\text { si Sun } \\
\text { Life } \\
\text { Financi } \\
\text { al } \\
\text { Indone } \\
\text { sia } \\
\text { (2012) }\end{array}$ & $\begin{array}{c}107 \\
566 \\
5\end{array}$ & $\begin{array}{c}214, \\
8314 \\
3\end{array}$ \\
\hline $\begin{array}{l}\text { Likuidi } \\
\text { tas }\end{array}$ & $\begin{array}{l}4, \\
70\end{array}$ & $\begin{array}{l}\text { Asur } \\
\text { ansi } \\
\text { Great } \\
\text { Easte } \\
\text { rn } \\
\text { Life } \\
\text { Indon } \\
\text { esia ( } \\
2016\end{array}$ & $\begin{array}{l}60 \\
26\end{array}$ & $\begin{array}{l}\text { Asuran } \\
\text { si Sun } \\
\text { Life } \\
\text { Financi } \\
\text { al } \\
\text { Indone } \\
\text { sia } \\
(2016)\end{array}$ & $\begin{array}{c}26,0 \\
889\end{array}$ & $\begin{array}{r}14,5 \\
3941\end{array}$ \\
\hline $\begin{array}{l}\text { Pertu } \\
\text { mbuh } \\
\text { an } \\
\text { Premi }\end{array}$ & $\begin{array}{c}- \\
41 \\
7 \\
7\end{array}$ & $\begin{array}{l}\text { Asur } \\
\text { ansi } \\
\text { Allian } \\
z \text { Life } \\
\text { Indon } \\
\text { esia ( } \\
2013\end{array}$ & $\begin{array}{r}490 \\
, 87\end{array}$ & $\begin{array}{l}\text { Asuran } \\
\text { si Sun } \\
\text { Life } \\
\text { Financi } \\
\text { al } \\
\text { Indone } \\
\text { sia } \\
(2012)\end{array}$ & $\begin{array}{l}48,6 \\
838\end{array}$ & $\begin{array}{l}82,6 \\
0654\end{array}$ \\
\hline
\end{tabular}

\section{Hasil Uji Asumsi Klasik}

Uji asumsi klasik bertujuan untuk memperoleh nilai penduga yang tidak bias dan efisien dari suatu persamaan regresi linier berganda dengan metode kuadrat terkecil biasa (Ordinary Least Square), maka dalam pelaksanaan analisis data harus memenuhi syarat uji asumsi klasik, sebagai berikut : Uji asumsi klasik yang pertama adalah uji normalitas dengan menggunakan pendekatan uji kolmogorov - smirnov test pada tabel 4 .
Tabel 4 Hasil Uji Normalitas One - Sample Kolmogorov - Smirnov Test

\begin{tabular}{lr}
\hline & Unstandardized Residual \\
\hline $\mathrm{N}$ & 50 \\
Kolmogorov - Smirnov Z & 1,114 \\
Asymp. Sig ( 2-tailed) & 0,167 \\
\hline Sumber : Hasil analisis SPSS diolah, 2017
\end{tabular}

Pada tabel 4 menunnjukkan bahwa nilai Asymp. Sig ( 2-tailed) lebih besar dari 0,05 yaitu sebesar 0,167 , sehingga data yang digunakan dalam penelitian sudah berdistribusi normal. Uji asumsi klasik yang kedua adalah uji multikolinearitas yaitu dengan melihat besarnya nilai dari Variance Inflation Factor ( VIF ) atau nilai tolerance pada tabel 5 , sebagai berikut :

Tabel 5 Hasil Uji Multikolinearitas

\begin{tabular}{lcc}
\hline \multicolumn{1}{c}{ Model } & Tolerance & VIF \\
\hline Rasio Perubahan & 0,702 & 1,425 \\
$\begin{array}{l}\text { Surplus } \\
\text { Rasio Beban Klaim }\end{array}$ & 0,769 & 1,301 \\
Rasio Biaya & 0,375 & 2,666 \\
Manajemen & & \\
$\begin{array}{l}\text { Rasio Likuiditas } \\
\text { Rasio Pertumbuhan }\end{array}$ & 0,805 & 1,243 \\
Premi & 0,354 & 2,824 \\
\hline
\end{tabular}

Pada tabel 5 menunjukkan bahwa nilai tolerance semua variabel $>0,10$ dan nilai VIF semua variabel < 10 sehingga dapat disimpulkan tidak terjadi gejala multikolinearitas. Uji asumsi klasik yang ketiga adalah uji heteroskedastisitas dimana tidak ada pola spesifik dalam grafik scatterplot, dimana titik - titik menyebar secara acak. Maka dapat diartikan dalam penelitian ini tidak terjadi gejala heteroskedastisitas pada model regresi linier berganda yang digunakan. Uji asumsi klasik yang keempat adalah uji autokorelasi, pada tabel 6 sebagai berikut :

Tabel 6 Hasil Uji Autokorelasi

\begin{tabular}{cccccc}
\hline $\begin{array}{c}\text { Mod } \\
\text { el }\end{array}$ & $\mathrm{R}$ & $\begin{array}{c}\mathrm{R} \\
\text { Squa } \\
\text { re }\end{array}$ & $\begin{array}{c}\text { Adjust } \\
\text { ed R } \\
\text { Squar } \\
\mathrm{e}\end{array}$ & $\begin{array}{c}\text { Std. } \\
\text { Error Of } \\
\text { Estimat } \\
\mathrm{e}\end{array}$ & $\begin{array}{c}\text { Durbi } \\
\mathrm{n}- \\
\text { Wats } \\
\text { on }\end{array}$ \\
\hline 1 & 0,5 & 0,33 & 0,255 & 413,80 & 2,187 \\
& 75 & 1 & & 229 & \\
\hline
\end{tabular}

Sumber : Hasil analisis SPSS diolah, 2017

Pada tabel 6 menunjukkan bahwa nilai DW sebesar 2,187 yang terletak antara DU sampai 4 - DU, yaitu nilai DU sebesar 1,7708 dan nilai 4 - DU sebesar 2,2292. Hal ini berarti 
menunjukkan bahwa tidak terjadi autokorelasi baik negatif maupun positif.

\section{Hasil Analisis Regresi Linier Berganda}

Hasil olah data dalam penelitian dengan analisis regresi linier berganda ditunjukkan pada tabel 7 sebagai berikut :

Tabel 7 Hasil Analisis Regresi Linier Berganda

\begin{tabular}{|c|c|c|}
\hline Model & B & $\begin{array}{l}\text { Std. } \\
\text { Error }\end{array}$ \\
\hline ( Constant ) & 1021,273 & 197,681 \\
\hline $\begin{array}{l}\text { Rasio Perubahan } \\
\text { Surplus }\end{array}$ & 1,758 & 1,573 \\
\hline Rasio Beban Klaim & $-8,675$ & 3,720 \\
\hline $\begin{array}{ll}\text { Rasio } & \text { Biaya } \\
\text { Manajemen } & \end{array}$ & $-0,205$ & 0,449 \\
\hline Rasio Likuiditas & $-13,432$ & 4,532 \\
\hline $\begin{array}{l}\text { Rasio Pertumbuhan } \\
\text { Premi }\end{array}$ & $-0,286$ & 1,203 \\
\hline
\end{tabular}

Pengaruh rasio early warning system terhadap financial solvency diuji dengan menggunakan teknik analisis regresi linier berganda dengan tingkat signifikansi 0,05. Dari hasil perhitungan dan pengujian maka dapat dibentuk model persamaan regresi linier berganda sebagai berikut :

$$
\begin{aligned}
Y=1021,273+1,758 \times 1-8,675 \times 2-0,205 \\
X 3-13,432 \times 4-0,286 \times 5+\varepsilon \\
\text { Berdasarkan model persamaan regresi }
\end{aligned}
$$

linier berganda tersebut dapat dijelaskan bahwa koefisien konstanta sebesar 1021,273 artinya apabila rasio perubahan surplus, rasio beban klaim, rasio biaya manajemen, rasio likuiditas, rasio pertumbuhan premi atau perubahannya sama dengan 0 , maka rasio financial solvency sebesar 1021,273. Nilai koefisien regresi rasio perubahan surplus sebesar 1,758 menunjukkan adanya pengaruh positif rasio perubahan surplus pada financial solvency. Nilai koefisien regresi rasio beban klaim sebesar - 8,675 menunjukkan adanya pengaruh negatif rasio beban klaim pada financial solvency. Nilai koefisien regresi rasio biaya manajemen sebesar - 0,205 menunjukkan adanya pengaruh negatif rasio biaya manajemen pada financial solvency. Nilai koefisien regresi rasio likuiditas sebesar - 13,432 menunjukkan adanya pengaruh negatif rasio likuiditas pada financial solvency. Nilai koefisien regresi rasio pertumbuhan pendapatan premi sebesar - 0,286 menunjukkan adanya pengaruh negatif rasio pertumbuhan pendapatan premi pada financial solvency.

\begin{tabular}{|c|c|c|c|}
\hline Variabel & $t_{\text {hitung }}$ & $t_{\text {tabel }}$ & Sig. $t$ \\
\hline $\begin{array}{l}\text { Perubahan } \\
\text { Surnlus ( } \mathrm{X}_{1} \text { ) }\end{array}$ & 1,117 & 1,67591 & 0,270 \\
\hline $\begin{array}{l}\text { Beban Klaim ( } \\
\mathrm{X} 2 \text { ) }\end{array}$ & $-2,332$ & 1,67591 & 0,024 \\
\hline $\begin{array}{l}\text { Biaya } \\
\text { Manajemen } \\
\text { X4) }\end{array}$ & $-0,455$ & 1,67591 & 0,651 \\
\hline Likuiditas ( X4 ) & $-2,964$ & 1,67591 & 0,005 \\
\hline $\begin{array}{l}\text { Pertumbuhan } \\
\text { Premi ( X5) }\end{array}$ & $-0,238$ & 1,67591 & 0,813 \\
\hline $\mathrm{R}$ & $\begin{array}{l}= \\
0,575\end{array}$ & & \\
\hline $\begin{array}{l}\text { Adjusted } \\
\text { Square }\left(\mathrm{R}^{2}\right)\end{array}$ & $\begin{array}{l}= \\
0,255 \\
=\end{array}$ & & \\
\hline$\Gamma$ hitung & 4,352 & & \\
\hline $\begin{array}{l}F_{\text {tabel }} \\
\text { Sig. } F\end{array}$ & $\begin{array}{l}=2,45 \\
= \\
0,003\end{array}$ & & \\
\hline Sig. $\alpha$ & $=0,05$ & & \\
\hline
\end{tabular}

\section{Hasil Uji Hipotesis}

Tabel 8 Hasil Uji Hipotesis
Secara simultan ( Uji statistik F ) dapat dilihat pada tabel 8 di atas, dengan membandingkan antara nilai $\mathrm{F}_{\text {hitung }}$ dan $\mathrm{F}_{\text {tabel }}$ serta nilai probabilitas signifikansi $<0,05$. Berdasarkan tabel dapat dilihat besarnya nilai $F_{\text {nitung }}>F_{\text {tabel }}(4,352>2,45)$ dan nilai probabilitas signifikansi sebesar 0,003 0,05. Maka dapat diartikan bahwa rasio early warning system yang terdiri dari rasio perubahan surplus, rasio beban klaim, rasio biaya manajemen, rasio likuiditas dan rasio pertumbuhan premi secara simultan berpengaruh signifikan terhadap financial solvency pada perusahaan asuransi jiwa syariah dalam penelitian ini. Secara simultan terlihat bahwa nilai koefisien determinasi $R^{2}$ sebesar 0,255, artinya bahwa rasio early warning system berpengaruh terhadap financial solvency pada perusahaan asuransi jiwa syariah di Indonesia pada 2012 - 2016 sebesar $25,5 \%$ dan sisanya dipengaruhi oleh faktor lain di luar variabel pada periode penelitian ini.

Secara parsial ( Uji statistik t ) dapat dilihat pada tabel 8 di atas, dengan membandingkan antara nilai $t$ hitung dan $t$ tabel serta nilai probabilitas signifikansi $<0,05$. Pada tabel di atas dapat dilihat nilai $t$ tabel sebesar 1,67591, apabila nilai $t$ nitung $>t$ tabel maka $\mathrm{HO}$ ditolak dan Ha diterima. Selain itu juga melihat besarnya nilai signifikansi, apabila nilai signifikansi $<$ 0,05 maka dapat diartikan bahwa variabel independen tersebut berpengaruh secara parsial terhadap variabel dependen. Nilai positif dan negatif pada nilai perhitungan hanya menjelaskan arah hubungannya.
Pembahasan 
Penelitian ini bertujuan untuk menguji pengaruh rasio early warning system yang terdiri dari rasio perubahan surplus, rasio beban klaim, rasio biaya manajemen, rasio likuiditas dan rasio pertumbuhan premi terhadap financial solvency pada perusahaan asuransi jiwa syariah di Indonesia selama periode 2012 - 2016. Penelitian ini dilakukan selama kurun waktu 5 tahun dengan jumlah data yang digunakan sebanyak 50 data laporan keuangan. Berdasarkan hasil analisis di atas maka pembahasan mengenai hasil penelitian sebagai berikut :

\section{Pengaruh Rasio Beban Klaim terhadap Financial Solvency}

Rasio beban klaim ( incurred loss ratio ) merupakan rasio yang digunakan untuk menilai proses penutupan risiko yang dilakukan oleh perusahaan asuransi jiwa syariah kepada nasabah / tertanggung ( Satria, 2012 : 171 ). Berdasarkan pengujian hipotesis diperoleh bahwa beban klaim yang diproyeksikan dengan beban klaim dibandingkan dengan pendapatan premi berpengaruh signifikan terhadap financial solvency pada perusahaan asuransi jiwa syariah di Indonesia. Pengaruh beban klaim berdasarkan perhitungan sebesar 8,675 pada periode 2012 - 2016. Maka dapat artinya bahwa semakin baik kemampuan perusahaan asuransi jiwa syariah dalam menyelesaikan pembayaran tagihan atau beban klaim, maka perusahaan dikatakan solvabel atau tingkat kecukupan dananya baik dan sebaliknya semakin rendah kemampuan perusahaan asuransi jiwa dalam menyelesaikan pembayaran klaim maka perusahaan dikatakan insolvabel.

Hasil penelitian ini mendukung penelitian dari Dewi ( 2016 ) dan Hasbi \& Suryawardani (2013) yang menyatakan bahwa beban klaim asuransi jiwa syariah di Indonesia berpengaruh signifikan terhadap financial solvency. Hasil penelitian ini juga sesuai dengan teori yang telah dijelaskan sebelumnya, yaitu beban klaim merupakan bagian dari rasio profitabilitas yang mengukur kemampuan perusahaan asuransi dalam menyelesaikan beban klaim terhadap tertanggung. Semakin tinggi kemampuan perusahaan asuransi dalam menyelesaikan pembayaran klaim yang terjadi maka perusahaan tersebut dalam keadaan solvabel atau tingkat kecukupan dana baik, dan sebaliknya semakin rendah kemampuan perusahaan asuransi dalam menyelesaikan pembayaran klaim maka keadaan keuangan perusahaan tersebut buruk atau insolvabel dan dapat dikatakan perusahaan mengalami kekurang cairan kondisi keuangan. Kemampuan perusahaan asuransi dalam memenuhi kewajibannya berkaitan dengan pembayaran beban klaim paling utama dipengaruhi oleh kemampuan perusahaan dalam mengelola pendapatan.

Pendapatan utama perusahaan asuransi adalah diperoleh dari pembayaran premi oleh nasabah. Premi yang telah dibayarkan nasabah selanjutnya akan dikelola oleh perusahaan sehingga menghasilkan nilai profitabilitas yang selanjutnya nilai profitabilitas tersebutlah yang akan digunakan untuk memenuhi seluruh aktifitas berkaitan dengan pembayaran. Akan tetapi jika perusahaan asuransi tidak dapat memenuhi kewajibannya dalam pembayaran beban klaim biasanya akan dilakukan pembayaran beban klaim oleh perusahaan penjamin asuransi atau perusahaan reasuransi.

\section{Pengaruh Rasio Likuiditas terhadap Financial Solvency}

Rasio likuiditas ( liability to liquid asset ratio ) merupakan rasio yang digunakan untuk mengukur kemampuan suatu perusahaan asuransi dalam memenuhi kewajibannya dan secara kasar memberikan gambaran kondisi keuangan perusahaan apakah solven atau tidak, digambarkan dengan jumlah kewajiban dibagi total kekayaan yang diperkenankan. Rasio likuiditas yang baik $<100 \%$, apabila mendekati $100 \%$ maka kondisi keuangan perusahaan dalam kondisi yang kurang baik ( Fahmi, 2014 : 59 ). Berdasarkan hasil pengujian hipotesis diperoleh hasil bahwa rasio likuiditas berpengaruh negatif dan signifikan terhadap financial solvency perusahaan asuransi jiwa syariah. Pengaruh rasio likuiditas berdasarkan hasil perhitungan sebesar 13,432 pada periode 2012 -2016. Maka dapat diartikan bahwa nilai likuiditas semakin rendah maka tingkat solvabilitas semakin baik atau tingkat kecairan dana perusahaan asuransi tersebut dalam kondisi yang baik dan sebaliknya.

Hasil penelitian ini mendukung penelitian Dewi ( 2016 ) yang menyatakan bahwa rasio likuiditas berpengaruh signifikan dan positif terhadap financial solvency. Hal serupa juga terjadi pada penelitian Krisnawuri ( 2015 ) yang menyatakan bahwa variabel likuiditas berpengaruh signifikan baik secara simultan maupun parsial terhadap variabel solvabilitas. Akan tetapi hasil penelitian ini tidak mendukung hasil penelitian Oktaviani ( 2015 ) menyatakan bahwa rasio likuiditas yang menjadi bagian dari rasio EWS tidak berpengaruh signifikan.

Hasil penelitian ini sesuai dengan teori yang dijelaskan sebelumnya yaitu rasio likuiditas yang tinggi menggambarkan kondisi keuangan perusahaan yang buruk dan sebaliknya jika rasio likuiditas rendah maka 
cenderung menggambarkan kondisi keuangan perusahaan yang baik atau solven. Hubungan negatif pada hasil perhitungan di atas dapat diartikan bahwa peningkatan rasio likuiditas pada EWS akan menurunkan nilai financial solvency perusahaan asuransi jiwa syariah, yang berdampak pada kesehatan keuangan perusahaan tersebut.

\section{KESIMPULAN DAN SARAN Kesimpulan}

Setelah melalukan penelitian pengaruh rasio early warning system terhadap financial solvency pada perusahaan asuransi jiwa syariah di Indonesia periode 2012 - 2016, maka dapat ditarik kesimpulan dan saran sebagai berikut :

Secara simultan rasio early warning system atau variabel bebas dalam penelitian ini yang terdiri dari rasio perubahan surplus, rasio beban klaim, rasio biaya manajemen, rasio likuiditas dan rasio pertumbuhan premi berpengaruh terhadap financial solvency pada perusahaan asuransi jiwa syariah di Indonesia periode 2012 - 2016.

Berdasarkan hasil uji statistik pada masing - masing variabel bebas dapat diketahui bahwa rasio early warning system yang terdiri dari rasio beban klaim dan rasio likuiditas memiliki pengaruh terhadap financial solvency perusahaan asuransi jiwa syariah di Indonesia. Rasio perubahan surplus, rasio biaya manajemen dan rasio pertumbuhan premi tidak memiliki pengaruh terhadap financial solvency perusahaan asuransi jiwa syariah di Indonesia dalam penelitian ini.

Rasio beban klaim dalam penelitian ini merupakan rasio yang berpengaruh dominan diantara rasio early warning system lainnya terhadap financial solvency perusahaan asuransi jiwa syariah di Indonesian pada periode 2012 -2016. Demikian kesimpulan yang dapat ditarik dari hasil penelitian ini selama kurun waktu 5 tahun pada periode 2012 - 2016.

\section{Saran}

Penelitian ini memberikan beberapa bukti empiris tentang rasio early warning system terhadap kinerja perusahaan asuransi jiwa syariah di Indonesia, namun hasil penelitian ini masih memiliki beberapa keterbatasan. Untuk lebih menyempurnakan temuan penelitian ini perlu dilakukan pengembangan penelitian lanjutan mengenai faktor lain yang ikut mempengaruhi rasio early warning system terhadap kinerja keuangan perusahaan asuransi jiwa yang berbasis syariah di Indonesia. Berdasarkan hasil yang didapatkan dari penelitian, maka peneliti dapat memberikan beberapa saran sebagai berikut :
Bagi Peneliti Selanjutnya diharapkan agar dapat mempertimbangkan penggunaan 13 rasio early warning system untuk lebih mengetahui pengaruhnya terhadap financial solvency, karena 5 rasio yang digunakan dalam penelitian ini belum mampu menjawab persoalan perusahaan asuransi syariah di Indonesia. Penggunaan 13 rasio early warning system diharap dapat memprediksi financial solvency lebih akurat dalam menilai kondisi sehat tidaknya perusahaan asuransi. Selain rasio early warning system ada kemungkinan faktor lain di luar rasio early warning system yang dapat digunakan oleh peneliti selanjutnya untuk melihat pengaruh terhadap financial solvency perusahaan asuransi jiwa syariah di Indonesia.

Peneliti selanjutnya dapat menggunakan variabel dependen lain seperti laba perusahaan yang diukur menggunakan rasio early warning system. Karena laba merupakan salah satu penentu keberhasilan dalam menjaga kestabilan kondisi keuangan. Adanya penerapan rasio early warning system diharapkan mampu meningkatkan laba perusahaan dari tahun ke tahun.

\section{DAFTAR PUSTAKA}

Asosiasi Asuransi Syariah Indonesia. 2014. Berita \& Kegiatan : AASI. http://www.aasi.or.id. Periode III.

Citra, Selly. 2012. Analisis Pengaruh Rasio Early Warning System dan Resiko Sistematik Terhadap Harga Saham Pada Perusahaan Asuransi Kerugian yang Terdaftar di BEI. Tesis. STIE Perbanas, Surabaya.

Detiana, Tita. 2012. Pengaruh Financial Early Warning Signal terhadap Perubahan Harga Saham pada Perusahaan Asuransi yang Terdaftar di BEI. Jurnal Bisnis dan Akutansi, 239 - 245.

Dewi, Tiara Trie Chandra. 2016. Pengaruh Rasio Pertumbuhan Surplus, Rasio Beban Klaim, Rasio Likuiditas, Rasio Pertumbuhan Premi, Ukuran Perusahaan dan Risk Based Capital terhadap Kemungkinan Financial Distress Studi pada Perusahaan Asuransi Umum yang Terdaftar Di Direktori

Perasuransian Indonesia. Jurnal Asuransi \& Manajemen Resiko. Vol. 2. No. 3, Juli.

Ernest \& Young. 2010. World Bank and International Insurance Foundation. Jurnal Asuransi \& Manajemen Resiko. Vol. 3 No. 2, September. 
Fahmi, Irham. 2014. Pengantar Manajemen Keuangan . Cetakan Ketiga. Alfabeta. Bandung.

Grasson, V. 2012. Early Warning System : A State Of The Art Analysis and Future Directions. Kenya, Nairobi. United Nations Environment Programme.

Hasbi, H \& Suryawardani, B. 2013. Sistem Peringatan Dini sebagai Pendukung Kinerja Perusahaan Asuransi

Syariah. Jurnal Keuangan dan Perbankan. Vol. 17 No. 2 : 243 - 252.

Krisnawuri, Kurniawan. 2015. Analisis Kinerja Keuangan Perusahaan BUMN Asuransi yang Go Public menggunakan Analisis Ratio dan Risk Based Capital. Tesis. Universitas Sam Ratulangi, Manado.

Marliza, Erma, Noor. 2014. Analisis Faktor Faktor yang Mempengaruhi Terjadinya Kondisi Financial Distress Perusahaan Asuransi ( Studi pada perusahaan asuransi umum yang terdaftar di Direktori

Perasuransian Indonesia). Skripsi. Universitas Diponegoro, Semarang.

Nababan, C. N. 2011. Peraturan Pembukuan Perusahaan Asuransi. Rajawali Press. Jakarta.

Nafis, Chandra. 2013. Mengenal Asuransi Syariah. Cakrawala. Yogyakarta.

Oktaviani, Maria. 2015. Early Warning System dan Pertumbuhan Pendapatan Konstribusi Pada Perusahaan

Asuransi Jiwa Syariah di Indonesia. Jurnal Keuangan dan Perbankan. Vol. 19. No. $2: 271-282$.

Prasetyo, Akhmad. 2015. Analisis Pengaruh Rasio Keuangan Early Warning System terhadap Tingkat Solvabilitas Perusahaan Asuransi di Bursa Efek Jakarta. Tesis. Universitas Diponegoro, Semarang.
Priyantina, Meida. 2015. Analisis Struktur Kepemilikan dan Kinerja KeuanganEarly Warning System terhadap Nilai Perusahaan. Jurnal Akutansi Pascasarjana Universitas Syiah Kuala. Vol. 3. No. $2: 64$ -75 .

Puspitasari, Novi. 2015. Manajemen Asuransi Syariah. UII Press. Yogyakarta.

Puspitasari, Novi. 2011. Manajemen Keuangan dan Strategi Perusahaan Asuransi Umum Syariah di Indonesia. Jurnal Manajemen. Vol. 15. N0. 3. Oktober 2011.

Sanusi, Anwar. 2016. Metodologi Penelitian Bisnis. Cetakan Keenam. Salemba Empat. Jakarta.

Satria, Salustra. 2012. Pengukuran Kinerja Keuangan Perusahaan Asuransi Kerugian di Indonesia dengan Analisis Rasio Keuangan Early Warning System. Lembaga Penerbit Fakultas Ekonomi UI.

Smirnov, S.N \& Zdoro Venin. 2012. Risk Based Assesment of Deposit Insurance Fund Adequency. $\quad$ SSRN Working Paper Series

Vuuren, L. Jansen Van. 2017. Assessing the impact of Solvency Assessment and Management on Risk Management in South African Insurance companies. Journal Southern African Business Review. Vol. $21: 129-148$.

Zanora, Vinzen. 2013. Pengaruh Likuiditas, Leverage dan Aktivitas dalam Pertumbuhan Laba. Jurnal Akutansi. Vol. $3: 77$ 100 